DOI https://doi.org/10.36059/978-966-397-174-2/128-152

\title{
STIMULATION OF THE PROCESS OF FINDING CREATIVE SOLUTIONS OF SOCIAL REHABILITATION OF TEENAGERS IN THE CONDITIONS OF A MODERN UKRAINIAN FAMILY: ART THERAPRUTIC ASPECT
}

\section{Khyzhna O. P., Slabko V. M.}

\section{INTRODUCTION}

At the process of the integration to the European higher education area, the Bologna process required significant changes in the methodology of higher education on the basis of humanization, democratization, fundamentalization and new approaches to the education and training of the future teachers. The problem of choosing the essential ways of improving the Ukrainian educational system is actualized: on the one hand, how to preserve the best achievements of the national educational thought, on the other, how to follow the common European requirements for joint education area.

These problems require highly qualified trained specialists, who are not only capable to creative professional fulfillment and can to attract the younger generation to a deep knowledge in the studies of Nychkalo (2016), Khyzhna, Lendel-Sarkevich (2018), Jacyno (2007) and considers the following issues cultivation of social differences, lifestyle as a way of self-expression, the art of living, techniques of self-creation.

Truflarowa et al. (2015) introduce such local issues of contemporary family wich are considered by the authors as most impotant. There is an urgent need to reform the educational system in Ukraine according to the current trends of society to protect children from negative influence. Special attention in the implementation of this work requires such vulnerable children as homeless, neglected children, "street children", social orphans.

All the time family was base of Ukraine society, its essential part, making influence on all aspects of social life. As integral part of society, family accomplishes important social, ethnocultural functions, which 
connect it with all spheres of human life. Accordingly it is attraction of different sciences (sociology, demography, economy, psycology, pedagogics, medicine). Each of discipline appropriates approaches and aspects of family research. On speciality researches of family upbringing, forming family values, development family supersubstantiality as reflexion of society pedagogues and psychologists are concentrated.

Definition of term "family" explains Ukraine explanatory dictionary as "group of people which includes husband, wife, children and others relatives who live together". ${ }^{1}$.In contemporary reference literature there is definition of family as union of people on base on marriage or cosinage who connected by general of living and whole responsibility.

As a social phenomenon Ukraine family went through many hardships. Archeological researches and written sources of Kyiv Rus age, in particular "Ruska Pravda" of Yaroslav the Wise shows existence of monogamic family (one husband has one wife) from territory from time of its settlement. Such type of family if the most typical today.

Sociologists devide monogamic family on "traditional" and "extended". "Traditional" family consists of one couple (or one of parents) with unmarried children (or without them). This family can be different types: wedded couple, two-traditional family - parents and children, one-parented family (one parent and children). "Extended" family consists of several cognignated families; each of one is traditional or extended. Extended family can be partnted family (after parent's death married brothers and sisiters live together). Another type of traditional and extended family is "family community", which consists of one married couple with children and other relatives (wife's or husband's father, their sisters or brothes.) This type family has been excisting for a long time.

Archeologists approve excisting on Ukraine's territory from Late Stone Age (35-40) different types of families: traditional, extended, communities. From time to time they have been transformimg: traditional families transferred to extend or communities or extended

\footnotetext{
1 Великий тлумачний словник сучасної української мови / укл. О. Єрошенко Донецьк: ТОВ «Глорія Трейд», 2012. - 864 с. - С. 604.
} 
family changed in one-parented family. Although it was typical for Ukrainians tendency to living separately.This explains by particular psychological features and individuality of national mentality: Ukrainian people consider liberty, private property, households on smallest part of ground the best of their value.

As M. Stelmahovich $(1998)^{2}$ considers, from anscient time cult of home-fire, cult of Race was typical for Ukrainian people. They had in their pantheon the gods Rid and Rozshanitsa that guarded family. Human without family and fireside was unhappy. Anscient legend said "without family there is no happiness on the Earth". Cult of Race was replication of genetic code. Races honor demanded to behave properly, to be the best for others. Honor of ancestries was in value, family traditions, "rushniki" and personal things trasfered from generation to generation; ancestry graves tended carefully. Factor of united and respected family was traditional holiday, when the all members of family gathered one table, spoke to each other and reconstructed family union.

During all time Ukrainian family was built on base of inwardness and belief, united with nature, as M. Stelmahovich (1985) considers getting space vivification (father - Moon, mother - Last Post, children - Stars). Family was united by different national-culture gaieties: Ukrainian family honor Ukrainian fables, folk-songs, native language. Child obtained national culture, language and moral standarts. By the way of practical receive such basis as love and honor of parents, family, agreement, cognation, gravity to native home, culture and language it obtained natural necessity to form future family on basement of previous race.

But it is necessary to argue, that features Ukrainian family had in past time. Today recessionary state of Ukrainian society reflects on family. Today it is important to research conditions in differences in Ukrainian family, analyse their negative recessionary aspects that needs transformations:

- Generalization of sociological researches gives opportunity to distinguish such specialities of modern Ukrainian family.

2 Stelmakhovich M. G.(1998), Novitni perspektyvy simejnogo vykhovannia // Ridna shkola, 1998. - № 7-8, C. 23-25. 
- Transformation of parents and children values. Modern young people changed their minds about charity, now deceived. In value system of modern young family tendency to becoming welth, upbrining pragmatic, rational, willed, successful children prevail. Kindness, skills to commiserate and help another people often are underestimated.

- Separation young from extended family. In modern times - its objective process, which determined by social-economical development of society. Young families tend to self-appraisal, don't take into consideration adult experience, don't develope family traditions, keeps everyday difficulties, professional problems. These all factors have negative effect on childrens upbringing process in family.

- Reduction processes in family. Decresse in birth is caused by rivalry increasing of job hunting, marriage processes, increasing of money spending on upbringing, bad household conditions and selfish tendention of parents "to live for themselves". Reducing of one-children family causes detachment from children because they don't have an example of care and honor to other people.

- Reduction of positive effect of social environment to family development. Urbanization of society, pragmatism of life, lack of family communication; so moral example on base of state human policy transforms system of life priorities and family values.

- Misunderstanding by parents system of forming human relationships with children, their tendency to role or self position. As the result childrens' subtraction from parents, limitation of relations within household. Sometimes parents depreciate moral and psychological relations in family, mutual respect, care. Harmony of family upbringing depends of sencereness and honesty of love to children. Children cannot develop within advance feeling, they want to be loved now and such as individuals.

- Expansion of non-traditional marriage relations - unregistered marriage. Economical difficulties, problems in job hunting, uncertainty in future caused civil marriage. One of representatives such relations consider civil marriage as preparedness to family life, display of self liberty, source of serving romantic relations. Other people consider that such type of family cause distrust, unstability. Such features of Ukraine family we consider as critical, which cause development of disfunction: 
increasing of dynamic of divorses, decreasing of birthrate, birth children of unwed parents, increasing of family conflicts, frustration; decline of material and spiritual prosperity.

As O. Khyzhna and O.Kondratyeva $(2016)^{3}$ considers, there is an urgent need to reform educational system according to the current trends of society to protect children from negative influence. Solution of this problem requires such vulnerable children as homeless, neglected children, "street children", social orphans, 93,4\% from them are temporary migrants.

According material of Justice Ministry (https://usr.minjust.gov.ua/ua/ freesearch), previous year there were rare marriage and more divorses. In 2016229,45 thousand of new families were registered, its 69,6 thousand less than in 2015. Number divorse on previous year became more than 1,2 thousand (35,46 thousand in 2018 according 34,2 thousand in 2017). Experts are assured, that sush statistic is a result of unbalanced socialeconomical and moral orientatuions in Ukraine.

Researches presented by Ukrainian sociologists, demographics and psycologists allow appreciate contemporary state functioning of critical Ukraine family. Results of scientific researches provide emphasizing of tendentions of functioning Ukrainian family:

- More popular becoming incomplete, non-marital family;

- Most men and women consciously don't marriage, but for satisfaction connect with sexual partner but not for family building.

- Material and rational motives of family building dominate.

- Young marrieds have tendency to one child.

- Young marrieds have uneduquate demands to partner and family, which cause family rejection and actualization in professional activity.

- More marriage couple are not able to cooperate, finding ways of normalizing relations, they are not skilled in solve of problems. All there factors creates divorse as instrument of deciding family conflicts.

\footnotetext{
${ }^{3}$ Khyzhna O, Kondratyeva O (2016) Preparation of social workers to work with teachers in the field of family support in the context of the present uncertain in Ukraine // Social Work in Uncertain Time. - Sbornik z conference XI I Hradecke dny socialni prace, Hradec Kralove 2 az 3 rijna 2015 / red Lucie Smutkova, Peter Patyj, Zuzana Truflarowa (Eds), Hradec Kralove: Gaudeamus:.268-273
} 
- Most young people oriented on encore wedding and extra-marital relations in case of unhappy alliance.

Supplied tendentions confirm positive aspects of old family molel are not functioned, new norms are not prepared. Situation of breaking family, inability to adapt to life changes, increasing of personal isolation demands help and creating immediate actions from state government, deputes, scientists, pedagogist, people who consider family as social value.

Whereas social and people relations became severe and pragmatic family must be symbol of inward and economical revival of Ukrainian state. Revival of traditional, high status of Ukrainian family, its authority, which based on fidelity, sincere love to children and their upbringing, honor to parents and mutual understanding in family formula to success of recovery and improvement of Ukrainian nation.

Basic vector of recovery Ukrainian family should be confirmation of system human value in kindness, wisdom, love, which provided by spiritual development. To inwardness (according researches of V. Andrushenko, I. Beh, I. Zazyun, S. Honcharenko, A. Maslow) refered people necessity in perception of world, meaning, goal of life, recognition specific value of family.

Psychological, pedagogical researches of phenomena of "inwardness" consider in context of substantial human harasteristics, matter of being, moral measurement of well-being, necessity for self-improvement. Term "inwardness" as O. Rudnitska (2005) ${ }^{4}$ defines, expressed by treasure of eternal human world, development of emotional, intellectual features, engaging to cultural value.

Inwardness is base of human and society eternal world, family. In time of social crisis, problem of inward development becomes national important. History approves perish of all civilasations began from gegradation of people inwardness. So, today is important to guide young family on inward values on base of kindness, respectability, honor, evil opposition for avoiding separate society, saving and development of Ukrainian family traditions as a part of socity. Future of Ukraine depends

\footnotetext{
${ }^{4}$ Rudnitska O. P.(2005) Pedagogika: zagalna i mystecka / O.P. Rudnitska - Ternopil: Navchalna knyga «Bogdan», 2005. - $360 \mathrm{c}$.
} 
on inward ideals, culture demand; interestings will be fullfiled life of each family. Inwardness is characterized by moral, ethic, esthetic problems and ideals, well-being of eternal world each family member and their interconnection, understanding and honor of each other, development of family traditions and honor of generation experience.Base of inwardness development is national and family traditions, which transfere to descent.

Traditions - elements which unite people, support generational integrity and relations. National traditions embrace all spheres of life, regulate family relations. Ukrainian family system, which historically developed during many ages, considers in family the main upbringing object is child, but subjects are parents, family, society. As a result typical pedagogical experience was formed, which then transferred in pedagogical wisdom, wshich was argued by M. Stelmshovich ${ }^{5}$, V. Suhomlinsky as "family pedagogy". It saves knowledge and experience to creating and save family, family traditions (labour, moral, artistic). Family pedagogy effects on forming love to parents, grandparents, honor of ancestries.

Family pedagogy is a part of national, which reflected in folk (fables, legends and songs), games, art, fest rites, traditions of labour and family upbringing. Family pedagogy always characterized as kind, which designates moral family vectors and ethic ideals, so it is a base of forming inwardness of Ukraine family.

Family became the first base of inward children upbringing. Inward ideals, signs, values, which are assimilated in young age, effect on future personal life. Upbringing in atmosphere of kindness, moral sencereness child is forming as harmony developed person. Family traditions, which transferred to next generations form essential skills in young age.

Principle tradition in Ukrainian family was labour, where each member has to work, even child. He takes part of household duties. Separation of household duties, main problems cause forming of conscientuos, mutual help and respect. Chidren which grow in family where labour is respected become successful and good professional in future.

5 Stelmakhovich M. G. (1985), Narodna pedagogika. - K.: Rad. shkola, 1985; Stelmakhovich M. G.(1998), Novitni perspektyvy simejnogo vykhovannia // Ridna shkola. 
Great importance for child upbringing and development inwardness in family are estethical traditions, which unite all family members to save comfort and create beauty and quietness at home and outdoors.

The problem of development and implementation of innovative forms and methods of social rehabilitation of children and youth, which include art therapy, faced the focus of many researchers. Noteworthy work of
A. Glinska-Lahovich,
L. Kunelska,
B. Loza,
M. Maukovska, E. Malakhovska, A. Mosiolek, A Panova, H. Poberezhna, N. Polyakova., A. Khmelnicka-Plaskota, O. Khyzhna, O. Kondratyeva, I. PateyukMazurek, S. Skeyfi, K. Shafranska, O. Voznesenska, and others.

Obviously, today is entirely appropriate to question the selfdiscipline - social pedagogy. Under the social pedagogy we understand industry pedagogy that studies the nature of social education to study peculiarities of the formation and development of personality in different mikrosotsiumah social environment. Professional orientation of future teachers' and social workers' innovativeness formed while studying at university.

\section{Theoretical foundations}

This time when the future teachers and social workers particularly sensitive to the complex problems of education, challenging teaching situations, consider sensitively to develop motivational value attitude to educational innovation. According to the analysis, many social workers practicing characterized by a low level of innovative behavior, commitment to innovation, which is largely the result of a traditional high school education.

New generation of educational innovations dictated by fundamental social and economic changes that have occurred in Ukrainian society with the transition from an industrial to a postindustrial, information society, and need "improve" the educational process, and its radical modernization. Despite the widespread use of innovation in terms of scientific and methodological work and research, analysis of implementing educational innovations indicates predominantly localized innovations in practice without proper conceptual understanding, theoretical and methodological support for the structural components of the training system. 
The concept of "innovation" (Lat. Innovatio - Update, change - a term borrowed from linguistics) in teaching science seen as ideas, approaches, tools, processes, results as partial, dramatic, local or complex purposeful change. Review of "innovation" in the educational context we define as innovation in all variety of structural components of the educational process (purpose, objectives of education, content-structural organization, technological support, forms and principles of communicative interaction) in order to qualitatively new features of the process and outcome of education according to the personal needs of future professional and modern society's demands. It is, in our opinion, to draw attention to the problem of tradition and innovation, to its multidimensional nature of social pedagogy, which is one of the main functions is the preservation of cultural traditions, which are based creative innovation.

The effectiveness of implementing innovations in the educational process depends largely on teachers. Teachers should realize the educational value of a qualitatively new type of teacher interaction, innovation on the functional-role level: changing technology monologic and dialogic learning polilohichnu technology teacher communication, collaboration with students in search and cognitive activities, replacing the role of "translator" of knowledge as a major source of educational information on activities - partner consultant (tutor), companion, colleague, facilitator (intellectual and psychological support) on the basis of mutual respect, cooperation, co-creation. The above functional role in the transformation of educational environment require adjustment technology teaching in dialogical context.

Chmielnicka-Plaskota (2014) considers: "unfortunately, most established educational tradition, teaching stereotype is performing the role of teacher reviewer opponent with fixing attention mainly on deficiencies that largely determines the appearance of the students insecurity in their abilities, slowing their professional development and self-development" ${ }^{\prime 6}$. One way to overcome this stereotype lies in

\footnotetext{
${ }^{6}$ Chmielnickia-Plaskota A, Łoza B, Mosiolek A, Patejuk-Mazurek I.(2014). Arteterapia w praktyce klinicznej. Warszawa: Wydał Oddzial Warszawski Polskiego Towarzystwa psychiatrycznego, towarzystwo "Amici di Tworki:11-18.
} 
providing students with the "right to error" attitude to mistakes as cognitive problems and initiate finding ways to solve students.

\section{Analysis and forecasting}

Today we have in developing of a family radical changes, which scientists call revolution. Sociologists selected the contemporary stage of family developing, name it as the second revolution in a family life, which not only changed radically the family relations, place and the role in society but as a big part of the scientists think, factually deliberate about a family existence. There are such social circumstances which gives a definite result:

- first, the growing economic independence of women and their involvement in the active employment (women is the desire for greater autonomy of traditional patterns of the family relationships, to change the traditional functions of the family, equality with men in decisionmaking, controlling costs and property family, etc.)

- secondly, the creation of two centers of the life - a place of work and home (early professional activities and household existed in unity within a family);

- third, the evolution of views on a sexual culture (the sexual revolution of the weakening of social control, increasing anonymity of sexual behavior, secrecy extramarital affairs and activities of a wide network of media that proclaim free sex love was not the primary measure of the level of civilization of modern men and women, changes in general social attitudes towards sexual behavior with a tendency to mitigate traditional notions of permissible and impermissible in this area);

- fourth, the invention of the reliable contraceptives and methods of preventing pregnancy (for the first time in human history, by such means failed to separate sex from conception).

Analysis of the influence of these circumstances points to their typical for all modern civilized world. Thus, we can conclude versatility of the comparable effects of these circumstances on the modern family to identify trends of its further development. There are such tendencies: 1) increasing the number of divorces (absolute and relative); 2) increasing the number of single-parent households and children born 
out of wedlock; 3) reducing the average length of the marriage; 4) the deposition time of marriage; 5) residence couples without marriage registration; 6) reduction of family size and birth of children, followed by an aging population as well as its depopulation; 7) an increase in the number of single people who are not married; 8) reduce the number of second marriages. It is clear that these tendencies are inherent to the development a family in Ukraine.

A family is the first and the main institute of a person's socialization. The process of assimilation and developing of the relation ways of a person to herself, others people, work, nature, the whole world and things take place in a family. Those values, which dominate in the family determine things which a child will assimilate as a first social experience.

In spite of the difference in family relations, there are the universal principles of the transfer and fixing of a human relation culture which is eternal part of the family education.

Moreover there isn't the single "'the global" conception in a family education, because of the difference of family education in the different nations.

A family is a bearer of the human and national ideals. The base of a person's self-identification is kept in it. Practically it is not limited in the opportunities of the common ways of education: A family carries out an important functions of socialization:

- Provide physical, intellectual and emotion development of a person;

- Forming sexual, ethnic, social identification of a child.

- Provide feeling of a person's safety

- Forming a valuable person's orientations

- Provide an acquirement of a child the base social norms.

In present time the family institute in Ukraine not always gives reasons for optimism: the negative influence of such factors as poverty, social and legal exposure of many social categories, inhabitation and others problems, unemployment, degradation of an educational system, traditional values of the education. As a result - the highest level of divorces of the "civil marriage" and therefore permanent decline in fertility in the country. 
In Ukraine for realization a state policy in this aspect the system of public institutions was formed, which carries out the powers in sphere of the child welfare and maternity:

- local State Administration (general management, identification and implementation of local programs) - Department of Social Protection, Department of Health, Department of Education, Services for the Minors, social centers for young)

- medical departments (medical and social rehabilitation of the minors, family planning centers, children's homes)

- departments of a care, education and training (juvenile shelters, schools and professional schools of social rehabilitation, the orphanages)

- social services for the young people (specialized social service, agencies of the social area, a group of the volunteers in social work);

- local authorities and institutions, which are not covered by local government organizations: law enforcement and correction agencies (criminal police Juvenile, educational and labor colonies, reception centers for the minors), the judiciary (courts, legal educators).

Glinska-Lahovich $^{7}$ (2015) introduces evaluation of both analysis and introspection results of cognitive activity of students have not yet acquired educational versatility: use assessment as a tool for learning and training motivational and emotional sphere students the skills of professional reflection, the need for self-improvement. In this context, it is important to consider the following aspects.

- reflection of a social worker on a psycho-pedagogical experience. You must learn how to analyze and varying conditions, factors that accompany them, and the results of local and large-scale teaching situations from other (primarily psychological) positions. Flexible approach to social and educational experience, professional analysis and selective evaluative attitude to previously learned techniques in conjunction with the assimilation of new psychological knowledge provides efficient synthesis of psychological and pedagogical knowledge, a new level of professional competence;

7 Glinska-Lahovich A (2015) Arteterapia w nauce i praktyce. Teotia - rozwój możliwości. wyd. Uniwersytetu Opolskiego:290. 
- reflection menus to use the analysis of social and educational activities and its results, covering assessment professional level, forecasting professional success, self-organization and self-diagnosis, maintaining stable operational feedback (from students, colleagues, administration);

- formation of reference retrieval position of the teacher regarding any aspect of his and "alien" (borrowed) socio-educational experience. Formation of this position provides a sound approach to the evaluation of capabilities and features of specific ways teacher interaction, determine the conditions and limits their application;

- formation of a holistic approach to the analysis of the problem of social and educational situations. The peculiarity of such situations in the educational process is the presence of a large number of participants with their roles, ways of interaction and interests. Therefore, attempts to solve the problem situation, relying only on local signs may fail;

- Forming ability to solve tasks collectively with other participants (students, colleagues). This provides the possibility to compare their views with those of colleagues, parents, finding optimal solutions not only due to maintain its position, but also through the analysis of other proposals, share their generation.

The leitmotif of art therapy rehabilitation program was the image of the house which was taken by us not by chance. We are considering the idea of home as an intimate, personal space, the basis of human life. Tiding up our house we also carry out cleaning of our soul. Home is the environment that surrounds us, it is not only the walls of the house. Home is primarily close relatives and also favorite subjects and animals - that is, everything that surrounds a person, forms his internal world.

Music therapy is a part of art therapy as one of the types of nonmedical therapy that deals with prevention and treatment of psychological disorders. Music therapy is an instrument of correcting emotional abnormalities, anxiety, motor and brain disorders, abnormalities in behavior.

In addition, music is a way of correcting functional, psychological or social variation. It is also a source of activating creativity. Padalka 
$(2008)^{8}$ identifies key aspects of music therapy: blocking the communication process with the social environment, preparation for use of psychotherapy and relaxation, support when relaxation associated with autogenic training, overcoming anxiety, adjustment fatigue, irritability, internal stresses caused by the stress state.

\section{Selected aspects of music therapy in the light of Leonard B. Meyer's theory}

The first concepts of theoretical approach to music therapy appeared in the fifties of the last century, however, if we look at these definitions we will notice that most of them do not meet the requirements of sufficiency and completeness. A slightly different approach is presented by researchers that treat the phenomenon of music therapy from the perspective of human sciences and medicine. Jan Wierszyłowski, author of fundamental works in the field of music psychology, discussing the psychological basis of perception of a musical work says: "music evokes a certain feeling, but the subjective state of the listener is of great importance in perception. The type of response to a musical work heard depends, on the one hand, on musical stimuli, on the other hand, on the listener's mental structure and extra-musical associations. In addition, on the perceptual type that he represents, current mental state and cultural habits"'. In another place of this work we read: "experimental data and music therapy practice show that music can change the activity of the nervous system, cause specific changes in the activities of the whole organism, can change muscle tone, accelerate metabolism, change the blood circulation rate, lower the sense sensitivity threshold senses, affect internal secretion, pulse strength and speed, modify breathing, etc."10, "acting as a kind of medicine"11.

Kinga Lewandowska believes that music therapy is: "one of the forms of psychotherapeutic and physiotherapeutic interaction that has a

\footnotetext{
${ }^{8}$ Padalka G.M. (2008), Pedagogika mystetstva (teoria i metodyka vykladanna mystetskih dystsyplin). - K.: Osvita Ukrainy.

${ }^{9}$ Wierszydłowski J. (1979), Psychologia muzyki, PWN, Warszawa 1979, . p. 225

${ }^{10}$ Wierszydłowski J. (1979), Psychologia muzyki, PWN, Warszawa 1979, p. 226

${ }^{11}$ Wierszydłowski J. (1979), Psychologia muzyki, PWN, Warszawa 1979, p. 79
} 
healing effect not only the psyche but also the whole human body" ${ }^{\prime 2}$. It can have a positive effect on the child's psyche but also, as a physiotherapeutic method, regulates the activity of the nervous system, reduces the degree of muscle tone, lowers the threshold of sensitivity of the senses, modifies breathing (Lewandowska K., 1996, p. 43).

Kinga Lewandowska divides music therapy into receptive and active music therapy. The first one includes listening to music, analyzing feelings and sharing them with the group, the second one - active play of music, instrumental, movement and vocal improvisations. Classes can be conducted individually or in a group of several people, depending on the diagnosis, symptoms and purpose of therapy.

There are attempts of sociological approaches in the literature on the subject - Gertruda Orff says: "music therapy is a multisensory therapy and musical means such as phonetic-rhythmic speech, free and orderly rhythm, movement, melody of speech and singing and hand-held instruments are used to suit all the senses. In spontaneous and creative cooperation, a child can and should freely formulate his way of expressing himself and use this in social relations" ${ }^{\prime 13}$. This approach brings us closer to the subject of speech therapy, which is after all a science of communication, as well as to sociolinguistic theories. The use of phonetic and rhythmic properties of speech as well as its melody (voice intonation, running a phrase in sentences) as elements of music therapy serves the development of communication skills and, consequently, socialization.

Meyer combined several areas in his work, for he was both an educated and creative composer, philosopher and cultural scholar as well as a theorizing musicologist. Probably just such a combination of interests and synergy of theory with practice enabled him to examine and formulate several cardinal principles of the essence and nature of musical experience. The key to a new look at the problem in this case turned out to be the communication aspect of music, usually overlooked in the first, classic period of formulating theories explaining the mechanisms of

\footnotetext{
${ }^{12}$ Lewandowska K. (1996), Muzykoterapia dziecięca, Studio „Norma”, Gdańsk 1996. P. 41

${ }^{13}$ Klöppel R., Villex S.(1995), Rytmika $w$ wychowaniu i terapii, przeł. A. Florek, PNO Studio Grafiki Komputerowej, Warszawa 1995, s. 45.
} 
music therapy. It is worth remembering that while the majority of researchers dealing with the subject of music impact on the recipient unanimously accept the possibility of transmitting various meanings through music in the process of perception and reception, but there is no unanimity at the stage of preliminary refinements. Some researchers claim that musical meanings are enclosed within the musical work itself (absolutists) while others (referentialists) are of the opinion that these meanings arise rather in the relationship between the musical work and the "non-musical" world and thus the world of concepts (including language concepts), activities or emotional states of the recipient. There are also researchers who believe that internal and contextual meanings are not mutually exclusive and can harmoniously complement each other. This dispute leads to one conclusion: the theory and practice of different cultures, over the course of historical eras confirms the possibility of "communicating" referential meanings, resulting from the relationship between the musical work and the recipient and cultural contexts in the broad sense of the term, through music. One of the proofs of this relationship are various "musical cosmologies," e.g. Hindu or Arabic ones, in the codified systems of which: tempo, pitch of the sound, rhythms, distribution of accentuation, timbre, nature of the instrumentation, as well as melorythmic sequences defined and respected by performers refer to specific concepts, feelings, moral and religious values. Similarly, although in a slightly different way, this happened in the musical "cosmologies" of Western countries, where the system of symbolic meanings refers to emotions, character traits or phenomena occurring in nature. In both cases we notice a certain type of cultural code, of a conventional nature, which attributes non-musical meanings to specific elements contained within a musical work on the basis accepted in a given cultural circle.

Meyer argues that there is a definition of musicality that does not refer to abilities commonly used as musicality parameters (such as: musical hearing, sense of rhythm, musical sensitivity), which emphasizes mainly the ability to understand musical form. The recipient expects the expected solutions and elements of meanings accepted in the given "system". If one could find a way to relate this expectation existing in the mental sphere to measurable and objective parameters such as the 
physiological responses of the body, one could examine the impact of these meanings on the emotional sphere of the listener on the basis of psychological theory of emotions. However, if we assume that these processes can be interpreted in the light of contemporary dominant communication theories, which emphasize reactivity, perhaps we could find the key to a specific interpretation of the therapeutic possibilities of music.

Music therapy techniques are divided into those that focused on emotional activation, training, relaxing, communicative, creative methods in the form of instrumental, vocal, physical improvisation and musical sensitivity training to develop the ability to see life in music discovery.

Music therapy is used both individually and in group sessions. Often it connects with other methods in the treatment. It is known that this type of therapy was used in ancient Greece, India, China as well as in Europe during the Middle Ages.

Music therapy requires the therapist enough depth knowledge of a psychology, medicine, and high-level musical training: possession playing musical instruments, singing skills and capability of musical improvisation. He must be able to organize and support the creative activity of the participants in the groups.

Only with the active participation of each student in these forms of work future specialist will emerge not only as a professional but also as a highly spiritual, fully developed personality. If society really interested to get educated generation of young people we should find an opportunity to strengthen the artistic component of the educational process in the Universities.

Thus, the willingness of future social workers and social workers to the introduction of innovative technologies implies that students' motivational value attitude to professional, possessing effective ways and means of achieving social and educational problems, the capacity for creativity and reflection, which in turn contributes to the successful productive activity. Further studies need scientific and teaching support credit-modular system of educational process in educational institutions; market research services and educational work to predict areas of socioeducational activities of future specialists. 
Theoretical analysis of scientific sources and the theoretical and methodological research allowed us to reveal the characteristics of art therapy as a method of rehabilitation. Art Therapy work, enabling the expression of thoughts, feelings, emotions, needs, states, like any art, gives a high positive mood and creates a proactive stance, selfconfidence, provides the need for self-actualization.

Analyzing content, features and possibilities of using art therapy techniques in working with teenagers, we determined effectiveness of their use in rehabilitation.

The main purpose of applying art therapy techniques is to help the child in a knowledging himself, creating a safe space of his inner world and free adequate expression of his own feelings out.

The use of art therapy techniques allows the child to achieve a state of psychological comfort: no matter what he is doing: creating a collage or invent stories. Art Therapy work gives a person an opportunity to express thoughts, feelings, emotions and needs, ensuring a high positive mood and creates a proactive stance, self-confidence, satisfying the need for self-actualization.

Art Therapy work with teenagers is a process that requires careful social pedagogic and sensitific approach to the child. Art therapist perceives teenager and certainly does not require any changes from a child gives him sense of security and trust, deeply believes in the ability of teenagers to act responsibly, respecting its autonomy in dealing with personal problems, appreciates the gradual rehabilitation process and not trying to speed it up.

Tasks of the art therapy program "House that I have built", we have identified as follows:

- to stimulate the creative potential of teenager as a permanent resource person;

- promote skills for understanding and adequate expression of his emotions and feelings;

- create conditions for self-expression and effective interaction of teenagers improve their communication skills and gain experience of social interaction and cooperation;

- develop a sense of team spirit, friendly relationship, compassion, empathy; 


\section{- empathy and mutual trust.}

To achieve the tasks we have developed and implemented a program that is a model of short-term, group art therapy session. Thus the emphasis shifted from medical and correctional goals for prevention, social, therapeutic, educational diagnostic.

The program included 10 sessions duration 60 minutes. Meetings frequency -3 times a week. The basic technique that we used include: drawing therapy, collage, fairy-tale therapy, drama, music therapy, elements of dance therapy, sand therapy, modeling.

We propose the following structure of the art therapy sessions with teenagers:

The first stage - setting - "setting on creativity". The task of this phase - training participants to spontaneous rhythmic activity and intragroup communication. It is possible to use games, dance exercises, simple visual techniques. Performing simple exercises provides reduced control of the minds relaxation.

The second stage - Update visual, auditory, kinesthetic sensations. At this point you can use the picture in combination with elements of music and dance therapy. Music as a therapeutic agent, according to many domestic and foreign scholars (S. Korsakiv, V. Behterev, K. Shvabi etc.) Affects a person's mood, improves his health, his will to stimulate healing.It is better to choose melodic songs without lyrics. You can combine art therapy and dance movement therapy.

The third stage - individual expressive activities. This phase includes individual creativity to explore their problems and experiences. It is believed that all kinds of unconscious processes, including fears, dreams, inner conflicts, early childhood memories are reflected in art production in spontaneous creativity. Moreover, visual arts classes, according to British art therapist S.Skeyfi, encourage the disclosure of internal forces of a person. Thus, non-verbal language tells people about their problems and feelings, helps to learn how to understand and analyze their emotions.

Participants usually differ in the degree of readiness of expression, contact with the art therapist to open his feelings. Some children and adults are trying to create realistic, beautiful pictures, so it is necessary to explain before the lesson that their work will not be assessed. 
We believe that plastic materials (clay, clay, dough) is most suitable for the expression of strong emotions and aggressive feelings and fears. Using a collage technique often helps to overcome uncertainty, situational anxiety associated with lack of artistic talent. Collective work on creating a collage helps clarify relationships in the group.

Fourth stage - intensification of verbal and nonverbal communication. The main task of this phase is to create conditions for intragroup communication. Each participant is invited to show their work and talk about it. The degree of openness of a person depends on the level of confidence in the group, to the art therapist, the personality characteristics of the child. If a teenager for some reason refuses statements should not insist.

Fifth stage - Teamwork in small groups. Participants come up with the plot and make a little performance. Translating traumatic experiences in comic form leads to catharsis, release from unpleasant feelings and emotions.

Sixth stage - reflective analiz. Final stage involves reflexive analysis in a safe environment. There must be present elements of spontaneous "mutual therapy" as a positive programming support. The atmosphere of emotional warmth, empathy, caring allows each participant of art therapy session endure the situation for success in any business. Teens gain a positive experience. In conclusion, it must be emphasized successes.

\section{CONCLUSIONS AND RECOMMENDATIONS}

Thus, considering the above, we can assume that art therapy has certain advantages over other methods of rehabilitation, namely:

- group art therapy gives teens the opportunity to know to what extent trust others their thoughts and feelings, and therefore ensures them psychological security,

- group art therapy gives teens a greater sense of their autonomy and thus satisfying one of the most important needs of a young person in maintaining independence and personal space,

- group art therapy provides teenagers the opportunity of mutual support and social self-determination.

The implementation of the above-mentioned conditions provides consistency in training to social and educational activities in the period of study at the university and at the stage of post-graduate education and 
in the methodical professional and pedagogical skills. It should identify the following promising areas of interaction of social work and social pedagogy in Ukraine:

- Create a separate body for the preparation of students for social and educational activities, whose purpose - to develop national education standards, licensing institutes and departments of social work, etc.;

- Enhancing the practical component of training for social workers;

- Attention to forming the professional ethics and personal development;

- Organization of cooperation with social services in the preparation of specialists in social work.

The willingness of future social workers to the introduction of innovative technologies implies that students' motivational value attitude to professional, possessing effective ways and means of achieving social and educational problems, the capacity for creativity and reflection, which in turn contributes to the successful productive activity.

Prepared for social and educational activities specialist has such a significant professional and personal qualities and characteristics:

- Awareness of the meaning, significance and purpose of social and educational activities in the context of the educational problems of art education in a multicultural society;

- Sensible, mature teaching position;

- Cultural tolerance;

- Ability to formulate new educational task of the subject, and achieve optimal rethink them during training;

- The ability to build a coherent educational program that takes into account the individual attention to students, educational standards, the new educational guidelines;

- Correlation of the reality with the requirements of individually oriented education, corrections of education process according to the criteria of innovation;

- Ability to see each individual abilities and teach according to their features;

- Ability to organize training and education to ensure that students creating their results and using innovative social and educational technology to stimulate their development; 
- Knowledge of technology, forms and methods of social and educational activities that provide skills based on personal experience and motivation of students to be co-creator of the purpose of their activities, to be competent tutor, consultant and assistant in correlation with outcome goals, using available student reflection and self-evaluation forms;

- Ability to see and encourage discoveries and cultural expressions of pupils;

- Ability to analyze changes in the educational activities, the development of personal qualities of pupils;

- Ability for personal development, reflexive activity, awareness of significance, urgency of their own research and discovery.

The prospects for the study of the above mentioned problem is to determine the patterns of deployment of arts education of future social workers, because the realization of education for credit-modular system requires significant new scientific and methodological and didactic approaches to planning and organization of the educational process, the methods of teaching and learning process, strengthen the role of independent work of students and changes in methods of teaching art disciplines. In a credit-modular system of education, the role of artistic training of future social worker who has to design artistic and pedagogical university environment using modern art therapy technology become higher and higher.

Thus, the key competence of teachers and social workers should include, along with the knowledge, skills and personal experience of the system of cognitive and practical skills, system relation to the content of future professional activity, emotional values, ethical and aesthetic components of the personal understanding and adequate level of professional motivation. Professionally- oriented competence under these conditions works as those that meet state standards.

Inwardness of Ukrainian family, best traditions of family upbringing must provide successful of future generation, for Ukraine independence, economical and political stability and high international authority. Ukrainian family must be base and symbol inward and economical reconstruction, goal of human activity of Ukrainian state.

A social work with young people as an important component of the national youth policy should be carried out taking into account the 
capacity of the state and its economic, social, historical, cultural development and international experience in this field.

Further development of the scientific understanding of the problem of the formation of the future social workers to work with bused children, requires consideration of the issues such as professional self and professional fulfillment of the future professionals by ensuring the quality of their education in a multicultural society.

The prospects for the study of the above mentioned problem is to determine the patterns of deployment of arts education of future teachers and social workers, because the realization of education for creditmodular system requires significant new scientific and methodological and didactic approaches to planning and organization of the educational process, the methods of teaching and learning process, trengthen the role of independent work of students and changes in methods of teaching art disciplines.

\section{SUMMARY}

This article discusses the problem of using art therapy in the process of stimulating the creation of creative solutions for the social rehabilitation of teenagers in a modern Ukrainian family. During the formation of new requirements for higher education in Ukraine, where the main condition is the formation of a modern generation capable of learning throughout life, finding and developing the values of civil society, able to consolidate the Ukrainian nation, integrate the Ukraine into the European Union as a compatible and well-developed country. Professional and pedagogical study of future teachers is a complex, dynamic and stable process that requires taking into account the needs of modern schools in professional teachers, capable of solving theoretical and practical problems in the learning process. The importance of modern professional training of future teachers and specialists in the social sphere and the search for rational methods for their professional training are disclosed.

Article deals with features of contemporary functioning and tendencies of Ukrainian family development. Traditions of Ukrainian family in histirical context are defined. Family as social phenomena is considered. Different types and varieties of Ukrainian family to their 
transformations are researched. Contemporary state of Ukrainian society has negative effect on family development according divorse and new family statistical information. Presented perspectives of national revival to determination of inwardness of Ukrainian family, necessity of the young people to self-development, independence, maintance of best traditions of family upbringing.

\section{REFERENCES}

1. Velykij tlumachnyj slovnik suchasnoi ukrainskoi movy / O. Yeroshenko - Donetsk: TOV «Gloria Traid», 2012. - 864 c. (in Ukrainian).

2. Cambridge International Dictionary of English. Cambridge: Univ. Press, 1995.

3. Chmielnickia-Plaskota A, Łoza B, Mosiolek A, PatejukMazurek I.(2014). Arteterapia w praktyce klinicznej. Warszawa: Wydał Oddzial Warszawski Polskiego Towarzystwa psychiatrycznego, towarzystwo "Amici di Tworki:11-18.

4. Glinska-Lahovich A (2015) Arteterapia w nauce i praktyce. Teotia - rozwój - możliwości. wyd. Uniwersytetu Opolskiego:290.

5. International Conference "Interregional Dialogue in Europe: 2001 and Beyond". - Analytical Report. - Kyiv, 2001.

6. Jacyno M (2007), Culture of individualism,Wydawnictwo naukowe PWN SA::35-62.

7. Klöppel R., Villex S.(1995), Rytmika $w$ wychowaniu $i$ terapii, przeł. A. Florek, PNO Studio Grafiki Komputerowej, Warszawa 1995, s. 45 .

8. Khyzhna O, Kondratyeva O (2016) Preparation of social workers to work with teachers in the field of family support in the context of the present uncertain in Ukraine //Social Work in Uncertain Time.- Sbornik z conference XI I Hradecke dny socialni prace, Hradec Kralove 2 az 3 rijna 2015 / red Lucie Smutkova, Peter Patyj, Zuzana Truflarowa (Eds), Hradec Kralove: Gaudeamus:. 268-273.

9. Khyzhna O, Lendel-Sarkevich A.(2018). Peace Education as Arts Education: In Search of New Strategies // Philosophy and Cosmology, Volume 21 The Academic Journal ISSN 2518-1866 (Online), ISSN 2307-3705 (Print), P. 74-84. 
10.Lewandowska K. (1996), Muzykoterapia dziecięca, Studio "Norma", Gdańsk 1996.

11. Nyczkalo N. (2016). Naukowe wzrastanie pedagogow // Badanie.Dojrzewanie.Rozwój (na drodze do doktoratu).- Metodologia nauk społecznych a metodologia badan pedagogicznych (red. naukowa F. Szlosek), Warszawa-Radom: Instytut Pedagogiki APS w Warszawie, Instytut Technologii Eksploatacji PIB w Radomiu:17-23.

12.Padalka G.M. (2008), Pedagogika mystetstva (teoria i metodyka vykladanna mystetskih dystsyplin). / G.M. Padalka. - K.: Osvita Ukrainy. (in Ukrainian).

13. Rudnitska O.P.(2005) Pedagogika: zagalna i mystecka / O.P. Rudnitska - Ternopil: Navchalna knyga «Bogdan», 2005. - 360 c. (in Ukrainian).

14.Stelmakhovich M. G. (1985), Narodna pedagogika.- K.: Rad. shkola, 1985. (in Ukrainian).

15.Stelmakhovich M. G.(1998), Novitni perspektyvy simejnogo vykhovannia // Ridna shkola, 1998. - № 7-8, C. 23-25. (in Ukrainian).

16. Truflarowa Z. (2015), Issues of contemporary family in the international context. - monograph / red Zuzana Truflarowa, Jana Levicka, Martin Smutek (Eds) // Hradec Kralove: Gaudeamus:8-23.

17. Wierszydłowski J. (1979), Psychologia muzyki, PWN, Warszawa 1979.

\section{Information about the authors: Khyzhna O. S.,}

Doctor of Pedagogical Sciences, Professor, Professor of the Department of Theory and Methods of Music Education,

Choral Singing and Conducting, National Pedagogical Dragomanov University 9, Pyrohova str., Kyiv, 01601, Ukraine

Slabko V. M.,

Doctor of Pedagogical Sciences, Head of the Department of Adult Education at the Faculty, National Pedagogical Dragomanov University 9, Pyrohova str., Kyiv, 01601, Ukraine 